\title{
Energy transition looming behind the headlines? Newspaper coverage of biogas production in Finland
}

\author{
Jari Lyytimäki ${ }^{1 *}$ (D), Nina A. Nygrén², Anna Pulkka ${ }^{1}$ and Salla Rantala ${ }^{1}$
}

\begin{abstract}
Background: Media coverage can play an important part in energy transitions. It creates awareness of landscapelevel megatrends affecting energy systems. It influences and is influenced by public and policy agendas on a regime level. On a niche level, it can spread or screen out information and motivate or discourage actors to adopt new technologies and practices. However, relatively few studies have specifically addressed the role of media in energy transitions. Newspaper coverage of biogas is studied here as a case of media framing of a potential renewable energy solution.

Methods: This article examines the long-term development of newspaper coverage of biogas in Finland. The aim of the quantitative content analysis is to draw an overall picture of the main phases of biogas coverage of a widely read newspaper focusing on agriculture and forestry, actors using discursive power in this coverage and key framings of the discussion. The results are discussed from the perspective of energy transition studies. In particular, future expectations created by the media are explored.
\end{abstract}

Results: The results show a lack of newspaper coverage on biogas in the early 2000s, followed by a rapid increase and stabilisation of the volume of newspaper coverage. Biogas was most often mentioned as a secondary topic of broader discussions related to renewable energy. The core discussion focusing on biogas was characterised by very positive framings of biogas as a preferable energy solution fully compatible with the principle of circular economy. The news stories often had a strong future orientation, and examples of enthusiastic forerunners were frequently presented. However, the coverage also emphasised the poor economic profitability of biogas technologies and a need for considerable public subsidies that are inherently unpredictable.

Conclusions: The future of niche-level energy technologies such as biogas can be strongly shaped by information flows, public perceptions and expectations created in part by media coverage. The analysed newspaper coverage in Finland was ambivalent from the perspective of energy transition. On the one hand, biogas production was represented as a preferable, environmentally friendly niche-level energy technology that should be encouraged. On the other hand, by emphasising the economic unviability of biogas technologies, the analysed newspaper coverage did not promote the adoption of biogas.

Keywords: Biogas, Bioenergy, Media coverage, Public representations, Renewable energy, Transition

\footnotetext{
* Correspondence: jari.lyytimaki@ymparisto.fi

${ }^{1}$ Finnish Environment Institute, Helsinki, Finland

Full list of author information is available at the end of the article
} 


\section{Background}

\section{Biogas as a promising renewable energy source}

Decentralised biogas production based on anaerobic digestion of organic material has been welcomed as an energy solution potentially addressing multiple environmental and socio-economic challenges. Biogas production can provide societies with new possibilities to turn residues and wastes into fuels, fertilisers and raw materials, thus supporting circular economy, which aims to minimise resource input and waste generation by creating material loops [1]. Controlled treatment of organic materials in closed bioreactors may also decrease harmful environmental impacts such as emissions of greenhouse gases $\left(\mathrm{CO}_{2}, \mathrm{NH}_{4}, \mathrm{~N}_{2} \mathrm{O}\right)$, acidifying substances, nutrient leaks, unpleasant odours and microbiological risks [2-5]. Biogas production can improve energy security by complementing the portfolio of local renewable energy sources. Unlike solar power which suffers from high variability of energy supply and a lack of means to store the energy, gas from bioreactors is relatively easy to store. Besides the environmental benefits, biogas production can create new employment opportunities and strengthen local and national economies. In particular, the potential for local livelihoods and employment opportunities for economically underdeveloped areas has been emphasised [6]. The assessment of economic profitability of different farm-level energy sources showed that under the current investment subsidy mechanisms, the economic profitability of biogas plants is better than that of energy production from oil or wood chips [7]. Recent advances of biogas technologies have opened up new opportunities for local-level experimentation while, at the same time, concern over climate change has contributed to overall public and policy agendas favourable of such new solutions.

Media reporting can further underline the positive qualities of small-scale biogas production because it has not been related to newsworthy negative aspects that have often characterised the reporting of several other energy sources. It has not been publicly characterised by images of dramatic and irreversible risks like nuclear energy has been, burdened also by the long shadow of atomic bombs and war industry [8]. It has generally not faced intensive public critique, complaints and controversies typical for the planning and construction of wind power [9]. Compared with non-renewable fossil fuels, biogas produced from renewable materials has an obvious advantage as a climate-friendly option. Small-scale or farm-level biogas production focusing on the utilisation of residues and side-streams is unlikely to face public criticism directed at large-scale and intensive use of agricultural land for energy production instead of food production [10, 11]. In Finland, forest-based energy has been promoted as a form of renewable energy but also criticised because of negative effects to water quality and biodiversity and increasingly due to climate impacts related to combustion of wood and decrease of forest carbon sinks. Biogas production based on waste and side-streams can avoid this critique of renewable energy as well.

Despite such promising characteristics, the development of decentralised, small-scale biogas production has been relatively slow in most countries and most of the biogas produced for energy use originates from largescale plants $[4,12,13]$. For example, biogas plays a relatively minor role in the Nordic countries characterised by high environmental consciousness and ambitious environmental policies. The renewable energy portfolio of Norway is dominated by water power, while wind power has a high profile in Denmark and forest-based bioenergy dominates in Finland [14]. Wood-based biogas was an important energy source in Finland during the World War II, when wood gas generators were widely used in civilian-motorised vehicles to save gasoline for military use [15]. After the war, the use of wood gas ceased. Contrary to countries such as Denmark, Finland did not introduce any ambitious policies aiming to promote more advanced biogas technologies during the late 20th century [16]. Compared to Finland, also the neighbouring country Sweden is characterised by a relatively strong role of biogas in energy policy and much wider use of biogas especially as a transport fuel. However, it has been estimated that only a small fraction of the biogas production potential in Sweden is currently utilised and especially the farm-based biogas plants suffer from poor economic profitability $[17,18]$.

Several explanations for the slow progress of biogas development have been offered, including relatively high investment costs and low economic profitability, missing financial resources, immature technologies and lack of information and expertise. Unpredictable energy policies and inconsistent government incentives have also been highlighted as key impediments [19-22]. One possible additional explanation is the quantity and quality of media coverage-or lack of coverage. The media plays an important part in setting the public and policy agendas and creating specific framings of renewable energy, hindering or enhancing technology diffusion, and selectively communicating information and misinformation [23-25]. Earlier research from various fields has shown that media representations can have a considerable influence on societal learning by giving prominence to certain opportunities or risks and neglecting others [26, 27]. Here, the focus is on the role of a sectorally oriented but widely read newspaper in energy transitions.

\section{Energy transitions and media representations}

Energy transition is here defined as purposeful, long-term and large-scale structural socio-technological transformation of the way energy needs are met $[28,29]$. Defining characters of energy transition include a high degree of 
complexity, different types of uncertainties, strong vested interests, path dependencies and lock-ins, participation of different types of actors and a key role for public policy. As noted by Geels et al. [30], low-carbon transitions of energy systems are contested and non-linear processes involving not only market diffusion of new technologies but also changes in user practices, cultural discourses and broader political struggles. Thus, the changes in energy technologies, practices and institutions are intertwined and co-evolving.

The multi-level perspective (MLP) [30-32] conceptualises energy transition as an interplay between the three levels of niche, regime and landscape. Niches form the micro-level of new innovations typically developed by small networks of dedicated actors outside of the market pressures. The socio-technical regime is the meso-level stable configuration of existing practises, mature technologies and institutions following a set of rules. Landscape refers to macro-level exogenous environment beyond direct influence of actors on lower levels. Changes in the landscape level are usually slow. Some landscape-level changes, such as climate change, may put pressure on the existing energy regime and inflict changes that may induce nichelevel innovations or technologies to become a part of a new modified regime.

Representations created by the media are a key factor setting the public and policy agenda of energy issues in contemporary societies [23]. They build public discourses and narratives that are vehicles of meaning and intermediation between individual and social spheres [33]. Media representations create shared awareness of landscape-level megatrends and boundary conditions of energy systems. During the past decades, the global adoption of new information and communication technologies as well as international consolidation of media companies have made the media contents more uniform.

Media representations are a key constituent of national socio-technical regimes of shared, stable and aligned set of rules or routines. Public framings created by the media can strengthen systemic lock-ins and path dependencies by supporting the existing power relations, actor positions and structures of energy system. On the other hand, critical media coverage can also destabilise current energy regimes and show that a variety of potential transition pathways are possible. Importantly, the media is not a monolithic actor but it includes multiple voices often delivering contradictory messages [23]. The social salience of these messages is a result of multiple factors, including scientific knowledge, values and emotions, institutional settings and individual preferences. As a result, the media agenda is both influenced by and influencing the public and policy agendas.

Media representations are also a key part of niche-level formation of new ideas and interactions. Media can create positive expectations that motivate niche-level actors to invest their time and money and to carry out potentially risky experiments that ultimately may lead to changes affecting the whole energy system [34]. Popular and professional media outlets can provide information and increase awareness among the public, entrepreneurs and policymakers about new energy technologies. Media, and increasingly social media, can induce interaction and information exchange between different parties, especially in the early phase of the innovation process [21]. On the other hand, media representations highlighting uncertainties and risks can discourage and forestall action [26, 35]. Information overflow or under-communication of certain information may prevent the actor from getting the relevant message in a suitable format at the right time. Unawareness may be maintained by the media omitting information on the development of certain energy technologies and related risks and opportunities. Media may also create unawareness by directing attention to other issues entirely out of the scope of energy transitions.

Earlier research has indicated that the topics highlighted and framings adopted by media representations over energy issues can show considerable variation. The variation can be high even between contexts that are relatively similar in physical, socio-cultural and economic terms [27, 36, 37]. This suggests that media coverage can play different roles in energy transitions. Even the information describing landscape-level global megatrends such as climate change and commonly agreed transnational climate policies can be domesticated in different ways in national and local settings [38]. Therefore, case studies can be valuable for identifying the key similarities and differences between various national contexts and for recognising the key issues concerning media representations that shape the development of energy systems.

\section{Research questions}

This study focuses on the role of newspaper coverage as a factor hindering or enhancing the transition towards a more sustainable energy system. The coverage is investigated over a period of 17 years in order to track long-term changes. Biogas is taken as an example of the debate over decentralised renewable energy technology potentially contributing to a transition of the energy system. The general aim of this study is to explore what kinds of public perceptions and expectations regarding biogas are created by the newspaper coverage and how they relate to potential transition pathways.

The more specific research questions are:

- How has the volume of biogas reporting evolved in newspaper coverage?

- Who are the dominant actors of the newspaper coverage focusing on biogas? 
- What types of framings are used to describe biogas production?

- What types of opportunities and risks relevant for an energy transition are highlighted or omitted in the media framings?

The study aims to provide insights into Northern European context and vernacular (Finnish) energy debates, thus complementing studies focusing on Englishlanguage media and major energy markets.

\section{Methods}

\section{The Finnish context}

Finland has identified itself as one of the global leaders of renewable energy. As touted by the State Energy Authority [39], Finland reached a new national record of renewable energy production in 2016, with over $40 \%$ of end consumption of energy covered by renewable energy sources. The record was explained mainly by the increased use of sidestreams in pulp industry, and in small part by investments in wind energy. The main source of renewable energy in Finland consists of black liquor and other side-streams of wood and pulp industry. The share of biogas is marginal. Only $0.5 \%$ of renewable energy currently originates from biogas, and about $0.6 \%$ of the biogas originates from farmlevel biogas reactors [40]. Most of the farm-level biogas reactors were launched during the past decade, and currently, there are approximately 20 operational farm-level reactors in the country. Most of the produced biogas originates from landfill gas recovery plants and water treatment plants.

Finland has a long tradition in utilising bioenergy. Historically, abundant forest resources have served as a key energy source vital for survival during the cold winters of the boreal climate region. Wood has remained an important fuel for the heating of detached houses, and currently, practically all new detached houses are equipped with a fireplace. Small-scale wood burning is also culturally significant as highlighted by the use of wood as a heat source for saunas, especially at the about 500,000 summer cottages of Finland [41].

In terms of the energy produced, centralised forms of energy production dominate in Finland. Heavy industry relying on a centralised energy production system has been one of the cornerstones of the Finnish economy. Together with the metal industry, forest industries led the industrialisation of Finland after the World War II. As a consequence, development of decentralised energy systems has not been presented as a significant target for the national energy policy until the past decade.

Recently, interest towards decentralised energy has increased considerably. It has been emphasised as a key factor for reaching national energy and climate targets and related EU-level and international goals [42]. A limited number of forerunners among both large and small energy companies as well as individual households have begun experimenting with decentralised renewable energy systems, indicating a potential for regime change [21]. Some consumer segments have showed a growing interest in locally produced, fossil fuel-free green energy. Media attention given to renewable energy technologies such as ground source heat pumps has increased as well [43]. Here, the focus is on the newspaper coverage of biogas.

\section{Newspaper data collection}

Data for this study originates from the newspaper Maaseudun Tulevaisuus (MT; "Future of the Countryside" in English). Despite its formal focus on the forest and agriculture sectors, the MT covers news broadly and is the second most read newspaper in Finland (excluding two tabloids), with a circulation of 76,091 in 2016 and estimated readership of over 330,000 [44]. Unlike other major newspapers in Finland, it has not faced a major decline in readership during the past decade. MT is published three times a week. The issues covered by MT pertaining to rural areas, agriculture and forestry and economic issues as well as natural resources and environmental policies can be considered highly relevant for energy transitions in general and for the development of biogas production in particular [4]. The newspaper acknowledges itself as an organ of the Central Union of Agricultural Producers and Forestry Owners in Finland (MTK). The newspaper is committed to following the good journalistic principles defined by the Finnish Council for Mass Media. It can be considered as a prestige or high-quality newspaper.

Newspaper items were collected using the online search tool of the digital edition, open for subscribers only. The search engine provided an opportunity for using wildcards ("). Use of wildcards is a necessity because of the inflexions of words in the Finnish language. Search was conducted during January 2017. Based on a testing of several keywords, the search term "biogas" (in Finnish: biokaasu*) was considered adequate to give a comprehensive picture of the coverage on biogas. The search included editorial material and opinion pieces including the search term anywhere in the title, figure, picture captions or text. Thus, the search included also items mentioning biogas only in passing. This methodological choice gives an opportunity to study how widely the issue is addressed as a secondary topic in debates focusing on other issues [45]. Remaining irrelevant hits not related on energy issues were removed manually.

The MT database declares that material is included from 1990 onwards but during the time of data gathering the first data available were from year 1999. The screening of raw data showed that the number of duplicates, missing items and errors was high in the 1990s and therefore the first year included in the sample was 2000. The 17-year 
time span was considered adequate to give an overall picture of the key phases of the newspaper reporting on biogas. Earlier research shows that coverage of non-wood biofuel production by MT's opinion and commentary sections was low during the 1980s and 1990s [46].

\section{Content analysis}

Content analysis aimed to draw a comprehensive overall picture of the coverage of biogas as well as a nuanced portrait of the debate focusing on the role of biogas in the energy transition. A two-step content analysis was performed. First, coding based primarily on the titles was used to identify whether the main focus of the news item was on biogas or some other issue. In unclear cases, sub-titles, figure captions and opening phrases were included in the assessment. This coding scheme remained at a general level since the purpose was to generate an overall picture of the longitudinal development of the newspaper coverage.

Second, news items focusing on biogas as a main issue were selected for a more detailed analysis. Coding included the tone of the item (positive, neutral or negative stance towards biogas), temporal orientation (focus on past, present or future of different lengths), spatial focus (local, sub-national, national or international) and actors (dominant or secondary actors). Four categories were developed to identify the dominant action framing of the news item [47]:

1. Diagnostic, i.e. the newspaper article identifies a problem by describing why an issue is a problem, what the consequences are or who or what is to blame for the problem.

2. Prognostic, i.e. the newspaper article involves the articulation of a proposed solution to the problem or the strategies for carrying out the planned activities.

3. Motivational, i.e. the newspaper article puts forward moral and motivational reasons why someone should be concerned about the problem and take action on it or ignore it.

4. Action framing not applicable to describe the news item. This category includes unclear cases that could not be unambiguously coded in categories $1-3$, which should fit most frames, as indicated by the low share of items coded as 4 .

Action framing is investigated especially in studies on social mobilisation [47]. Here, the action frame coding was applied to investigate whether the newspaper coverage was mainly analytic in its problem orientation or prognostic/motivational which might be linked to a potential to contribute to niche-level mobilisation of action and the eventual breaking of path dependencies in the current energy regime.
Cohen's kappa was used to test the intercoder reliability [48]. The test based on 25 randomly selected news items with 451 variables showed an excellent agreement between two coders $(\kappa=0.84)$.

\section{Results}

Overall development and key issues of the coverage

The attention given to biogas in MT increased during the study period of 2000-2016 (Fig. 1). The overall number of items mentioning biogas was 1,188 . On average, about every other issue of the newspaper included an item related to biogas. Most of the items mentioning biogas appeared in the section for domestic news. During the first years of the study period, biogas was relatively often mentioned on the news front page, indicating the novelty and high news value of the topic. After 2005, biogas was mentioned more often as a regular news item. Biogas was also increasingly discussed in op-eds and letters to the editor during the latter half of the study period.

The share of items focusing primarily on biogas was less than one quarter of all news items mentioning biogas $(n=282)$. Most of the coverage mentioned biogas as a secondary topic and focused mainly on other energy-related issues. News items mentioning biogas typically discussed it as one source of renewable energy. In particular, it was brought up in connection with forest-based bioenergy. The potential of biogas to complement other renewable energy sources such as solar or wind energy was discussed only rarely. Representations of biogas and wind energy potentially competing for the scarce public subsidies were occasionally created (MT Sept. 30, 2009).

The most prominent actors that presented their views or were described by the news items were biogas entrepreneurs and farmers (Fig. 2). These actor roles were often closely related and sometimes indistinguishable, since typical biogas entrepreneurs were also farm owners. These actors typically presented their views and future expectations related to a planned or recently launched biogas plant.

The acceleration phase of the coverage (2005-2006; Fig. 1) was characterised by attention given to forerunners of biogas production. The completion of the "Biovakka" biogas facility in southwest Finland was highlighted as a major investment requiring high technical knowhow. The facility required an investment of over six million euros and was able to treat sludge from 20 participating pig farms as well as additional biowaste (MT March 21, 2005). The experiences of a Finnish forerunner company, Metener Ltd, established in 1988, were also highlighted, and the CEO of the company was frequently interviewed by MT. Ten per cent of all the news items focusing on biogas mentioned this company and/or its owners. Metener Ltd operated the first farm-based biogas station in Finland aimed to serve private car owners. The company also develops biogas technologies. 


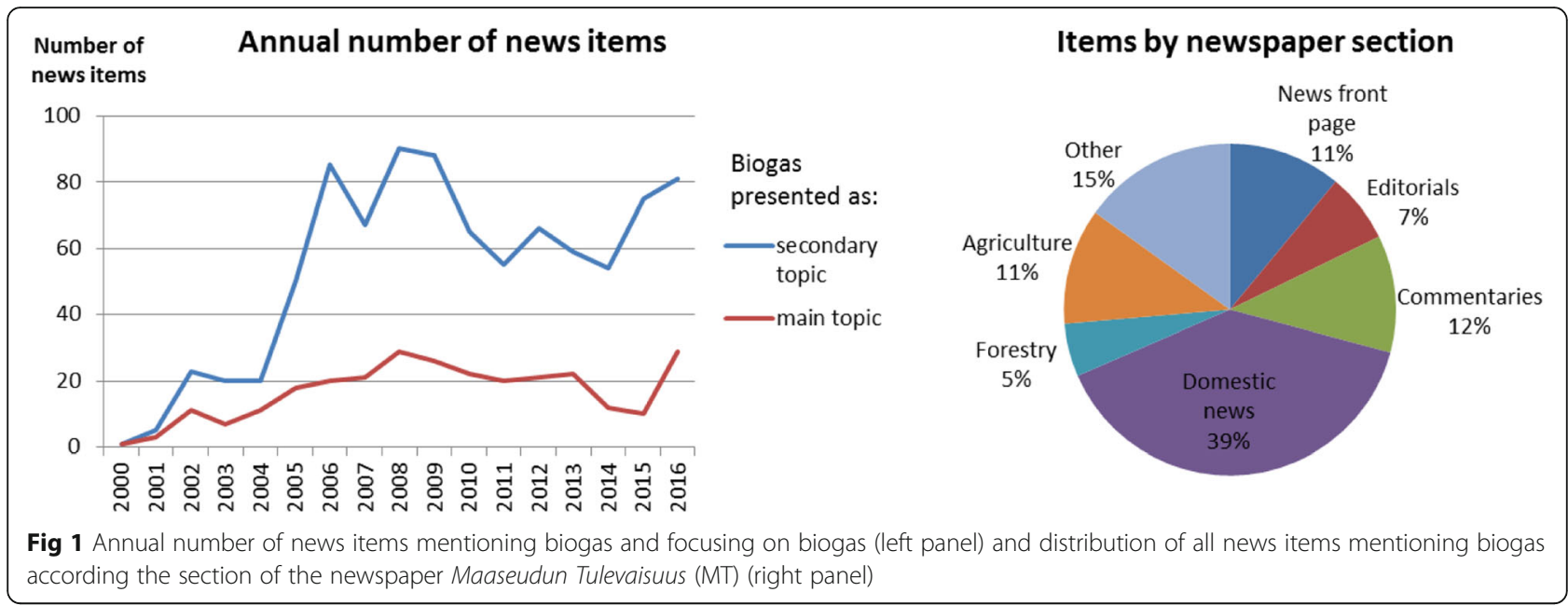

Research and development projects focusing on the development of biogas production were relatively often mentioned during the early 2000s (e.g. [49]). Interest and activities by key policymakers was an additional factor explaining the increase of news coverage. In particular, the biogas-fuelled car owned and driven by the Minister of Economic Affairs, Mr. Mauri Pekkarinen, gained considerable attention. The news reported about the keen personal interest by this top politician with a down-to-earth and even humorous headline: "Mr. Pekkarinen steps on the gas with manure gas" (MT Oct 11, 2006).

During the first 5 years of the study period, the news mainly described biogas as an environmentally friendly future energy solution. During the stabilisation phase of the coverage from 2007 onwards, the coverage was characterised by news on energy policy issues such as levels of investment subsidies and national targets for renewable energy. News about planned or operating biogas facilities were also occasionally highlighted. Biogas production was typically described as a potential solution to multiple environmental problems of agriculture. During the last years of the sample, biogas production was increasingly framed under the concept of circular economy. Actions by a well-

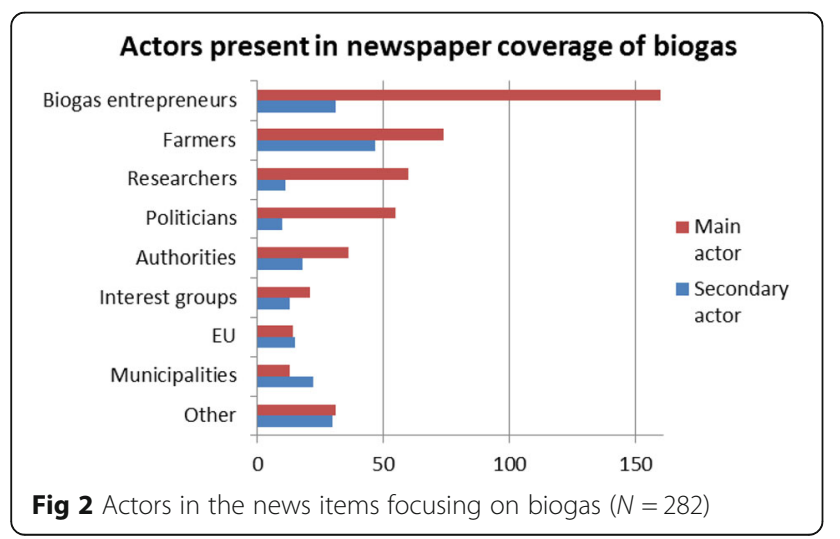

known business leader, Mr. Ilkka Herlin, were highlighted after he bought a large farm and initiated a new fertiliser business utilising biogas technologies and putting the principles of circular economy in practice: "Manure business starts at the Kuitia Manor" (Front page headline, MT July $15,2015)$. Climate concerns gave further impetus for biogas reporting even though climate change or climate policies were directly referred to in the sample articles quite rarely. National climate and energy strategies were specifically mentioned by two news items, and climate change was referred to in $9.2 \%$ of the items focusing on biogas.

\section{Key framings of the newspaper coverage}

The biogas coverage was in general strongly futureoriented since about a half (48.3\%) of the items focused on future development (Fig. 3). Furthermore, reporting focusing on the present situation often referred to future development implicitly. Spatial framings created an impression of biogas as a national-level issue. The reporting focused mainly on national policies and experiences from local biogas facilities. European Union was mentioned only rarely, despite the central role of EU targets on climate, energy and agricultural policies. EU bodies were referred to as primary actors by $5.0 \%$ of all items focusing on biogas. News focusing on other countries typically reported concrete examples of biogas production or related national-level policy measures by other countries. These news items represented Finland's biogas sector as underdeveloped in comparison with countries such as Sweden, Denmark, Germany or Austria.

The news coverage described biogas mainly with a prognostic framing, as a win-win energy solution simultaneously addressing rural economic development, treatment of manure and environmental issues (Fig. 4). Motivational frames were most prominent in the letters to the editor requiring introduction of policy measures supporting biogas. The coverage with farmers as key actors was characterised 

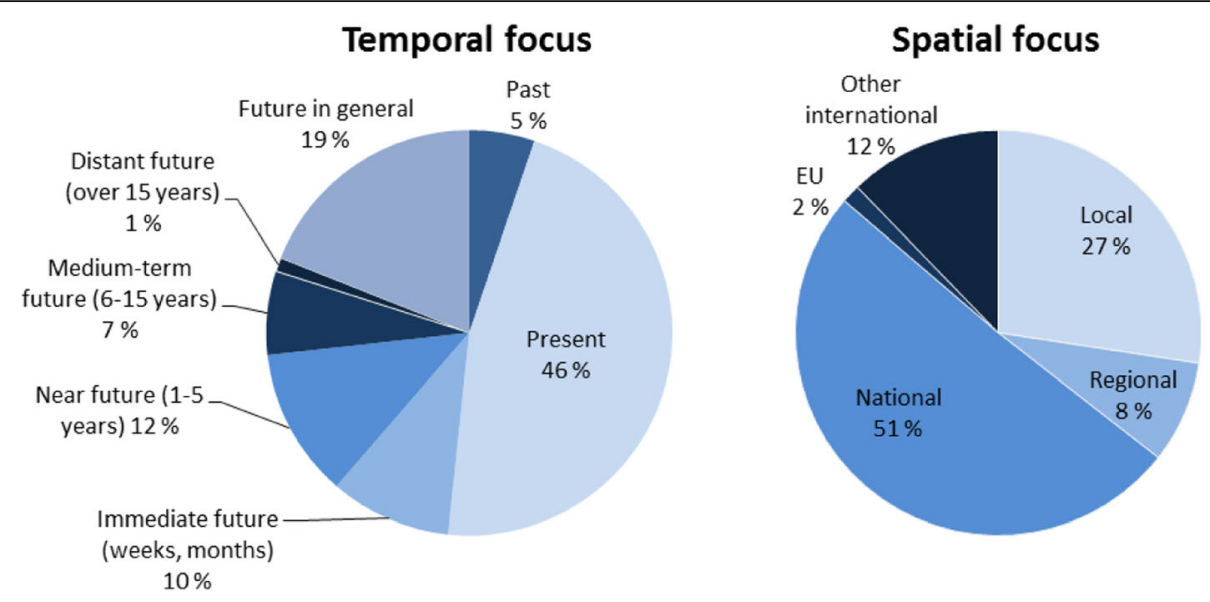

Fig 3 Temporal and spatial focus of the news items focusing on biogas

by a relatively high (16.2\%) share of motivational frames, indicating the interest of farmers to advance biogas technologies. However, the overall salience of motivational framings focusing on biogas was low. Items with a diagnostic frame typically addressed different impacts of biogas production.

In general, biogas was framed in a highly positive manner as a promising future energy source and a potential remedy for several challenges of the rural livelihoods. News items featuring a researcher as a core actor $(n=$ 57 ) had the highest shares of negative (5.0\%) or neutral (15.0\%) framings of biogas. The relatively high share of neutral reporting possibly indicates a lack of detailed science-based knowledge about the long-term implications of biogas production. However, the majority of news items with a researcher as the core actor had a positive framing of biogas (78.3\%).

Critical discussion focusing on possible negative social and environmental impacts of biogas production was almost completely missing. Technical uncertainties were occasionally discussed during the first years of the sample but such uncertainties were not a prominent theme and no major technical failures or risks were highlighted. The most

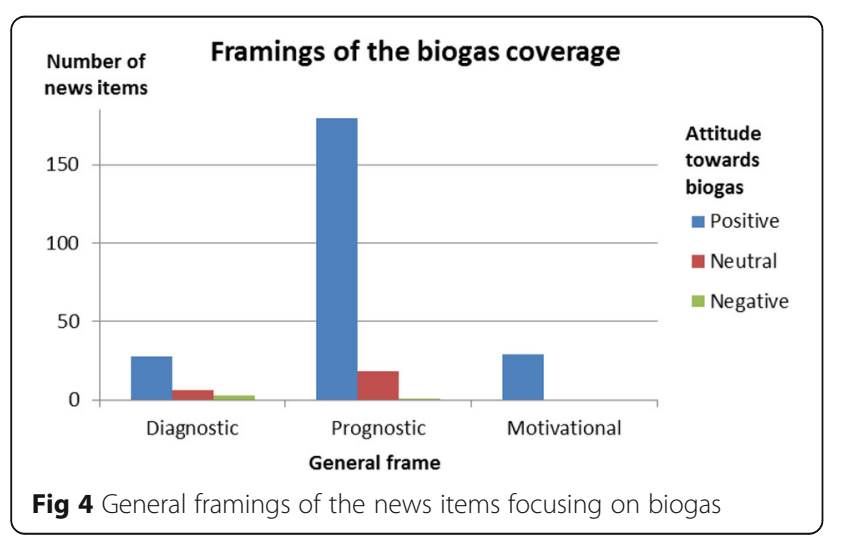

prominent critical theme was the economic feasibility of biogas production. Low profitability was a key concern, and the need for publicly financed investment subsidies was taken as a self-evident starting point. Energy cost savings created by the decreased need to buy energy for a farm was presented as the realistic economic potential while revenue sources, such as selling the electricity to the grid or producing biogas for traffic use, fees for taking in organic waste for treatment and economic benefits from using the digestate as a fertiliser, were generally considered as speculative or of minor importance.

Frustration with the slow progress of biogas development and lack of concrete support from authorities and policymakers was repeatedly voiced. In comparison with the highly positive future expectations and projections presented by some key policymakers, the actual development was perceived as slow in the news coverage. For example, the Minister of Agriculture and Forestry (Mr. Korkeaoja) stated in 2006 that the share of bioenergy will triple during the next 15 or 20 years and created expectations that biogas will substantially contribute to this increase (MT Nov. 29, 2006). In 2008, the Minister of Economic Affairs (Mr. Pekkarinen) demanded that in order to reach the national $38 \%$ target for renewable energy set by the EU, the use of biogas should be drastically increased, among other sources of bioenergy (MT Dec. $15,2008)$. Positive expectations were further highlighted by various calculations of the energy production potential, including front page news highlighting that it would take only about 2,000 cattle farms (about $10 \%$ of all cattle farms in Finland) to generate enough biogas to cover the needs of one third of all Finnish cars (MT June 9, 2008). Such positive expectations have been continuously highlighted in the news headlines such as the piece published in May 2, 2016: "Biogas takes a step forward". At the same time, the news coverage highlights that the leap from marginal to mainstream has not yet been realised. 


\section{Discussion}

Media can play an important part in energy transitions both by presenting information in a certain way or by not presenting it. Our results of the reporting of a widely read Finnish newspaper focusing on rural issues show that in the early 2000s, biogas was given only marginal attention as a potential local-level energy solution. The national-level energy debate was increasingly related to climate policy and focused mainly on forest-based bioenergy and nuclear power during that time [46, 50, 51]. The initial phase of the public (non-)discussion on biogas by MT can be considered as a case of unintentional inattention where relevant information exists but remains unnoticed [52]. This elongated phase of inattention was likely to considerably slow down the diffusion of biogas technologies. Examples from other countries were not brought up, and experiences of the domestic pioneers of biogas production remained isolated from the mainstream energy debates. In particular, experiences from neighbouring country Sweden could have provided useful lessons for the Finnish discussion $[17,18]$. Domestic research activities at the time were too sporadic to produce a continuous flow of easy-to-use material for the media [49]. The Finnish Biogas Association was established already in 1991, but as a small organisation based on the voluntary participation of a limited number of persons, it lacked the resources and public salience and credibility to efficiently serve as a knowledge brokering intermediary organisation. Compared to other interest groups of the Finnish energy policy, it has played only a minor role [53-55],

The second phase (2002-2006) of the discussion can be characterised as a gradual creation of discursive space favourable to niche-level development. The volume of media reporting started to increase as forerunners of farmlevel biogas production initiated their activities and provided the media with concrete news topics that were easy to report. Parallel to niche-level activities, statements by some prominent politicians favouring biogas as a preferable form of renewable energy gave further impetus for the reporting and challenged the prevailing energy policy regime. Biogas started to gain some prominence as a potential future energy source complementing the national renewable energy portfolio also because of assessments and various calculations suggesting considerable energy potential from agricultural crops and various organic residues (e. g. MT May 12, 2005). This framing was likely to induce expectations on economic opportunities provided by biogas production. More generally, in the early 2000s, the Finnish media debate on energy issues faced a shift from considering environmental concerns in terms of additional cost to considering them also as economic opportunities [56].

The highly positive tone of the biogas coverage is noteworthy, even though in part it can be explained by the orientation of the MT as a newspaper focused on rural development. During the stabilisation phase of the discussion (2007-2014), biogas was almost uniformly considered as a solution with potential to address environmental critique of farmers. The positive framing grew even stronger as the news coverage started to highlight biogas production under the concept of circular economy. During the last years of the sample (2015-2016), a more holistic framing of biogas emerged, emphasising not only production of renewable energy and reduction of greenhouse gas emissions but also other environmental effects such as the increased efficiency of the use of natural resources and possibilities to close nutrient loops. Biogas technologies were seen not only as a form of bioenergy but as a wider bioeconomy solution capable of delivering multiple benefits advancing the general policy objectives of rural development. This framing of biogas as an energy technology completely in line with the principles of circular economy is likely to serve as a strong legitimating factor in the future energy policy debate $[57,58]$. A similar shift in the biogas discussion from energy production to manure treatment has happened in other countries such as Denmark and the Netherlands $[59,60]$.

However, even though the MT framed biogas production as environmentally beneficial, technically advanced and socially acceptable, it also casted serious doubts by highlighting it as economically risky or even unviable under current market conditions. The need for considerable investment subsidies was taken as a self-evident starting point by the news coverage. Debate over the poor economic performance of small-scale biogas production has been a common theme in other industrialised countries as well [14, 17, 57, 61]. In the Finnish case, the news reporting that highlighted economic risks and the reliance on public subsidies was likely to deter potential early adopters even when concrete examples and learning opportunities based on the activities of forerunners were available. The lock-in faced by nichelevel actors was strengthened by the stagnating national economy and the poor economic outlook of the agricultural sector.

The coverage by MT showed some peculiarities originating from the Finnish context. In several other countries, such as Germany, criticism of global consequences of bioenergy potentially influencing food security has put the biogas sector under pressure ([61], p. 146). One explanation for the missing critical tone is that the news coverage strongly focused on the national and local levels. Land use competition between energy crops and food production was not framed as a key issue in Finland. On the contrary, energy production was framed as a prerequisite for sustainable agriculture following the principle of circular economy. For example, an opportunity to utilise crop residues and 
cover crops cultivated simultaneously with the main cultivated crop was brought up. In addition to producing extra material for bioreactors, cover crops can reduce nutrient leaching and improve soil structure and lead to positive long-term impact on main crop yields [58].

Other explanations for the missing critical tone include the small size of Finnish biogas plants and the benefits related to late adoption of technologies already tested elsewhere. The size of Finnish biogas plants utilising material from agriculture has remained relatively small, and large industrial-scale biogas plants that are criticised in other countries are missing [61, 62]. The short history of the majority of Finnish biogas plants provides an additional explanation. Critical insights may be increasingly presented especially if the positive expectations are not met. In Denmark, attitudes towards farm-scale plants and centralised plants have shifted several times since the beginning of the country's biogas production (the late 1970s). Negative experiences (low yields, lack of knowledge) from the first farm-scale plants encouraged the building of centralised biogas plants, but the uncertainty created by the liberalisation of the energy regime in the late 1990s resulted again in negative expectations towards centralised plants [16]. As highlighted by Geels and Raven [16], the question is fundamentally about long-term multi-level interactions of attitudes and interests in technological niches. One key question for the development of the Finnish biogas sector is the ability of family-owned small farms to create coalitions and networks capable of utilising windows of opportunity potentially opened by changing energy regimes or external landscape-level shocks.

The news coverage of biogas had a strong future orientation but detailed critical debate anticipating and evaluating the future potential of the technology was largely missing both regarding practical niche-level technologies and national-level energy policy. This is partially explained by a strong focus on domestic issues of the Finnish energy and agriculture sectors and relatively scarce reflection on experiences in other countries. During the recent years in particular, the coverage in MT increasingly highlighted the economic subsidies as a key issue for the future development of the biogas sector. This has shifted the focus towards national-level policy issues from niche-level technological development and potential disruptive technologies challenging the current energy system. For example, reporting connecting biogas production with hydrogen economy [63] or other future energy technologies was completely missing from the news agenda. Thus, long-term implications of present day energy solutions were poorly addressed. Lack of coverage over technical details and experiences from the use of biogas plants decreased opportunities for learning about the specific local characteristics of biogas plants.
Another issue largely missing from the news agenda was the role of consumers. This is partially explained by the professional orientation of the MT and its readership, consisting of a high proportion of farmers and forest owners. Consumer preferences are an important part of the dynamics of energy markets and the long-term development of energy systems. Consumers can be an important group for small-scale biogas producers, in particular because excess biogas can be sold as vehicle fuel. The profitability of selling biogas as fuel is dependent on the number of gas vehicles and the willingness of the vehicle users to buy local biogas which is slightly more expensive than conventional natural gas. Currently, the number of gas-powered private cars in Finland is about 2,000. The national target set for the year 2030 is 50,000 gas-powered vehicles [42]. Media coverage of energy consumption is important both because it can inform and help energy producers to address the needs of consumers but also because it can influence consumption patterns, for example, by increasing consumer awareness of available choices such as biogas.

The current Finnish energy policy emphasises the role of bioenergy for reaching the national renewable energy targets. As shown by the news coverage of MT, biogas has generally been seen in a very positive light, but in practice it has been given only a minor role in energy policy. A partial explanation for that can be found in the sector-based policymaking culture incapable of taking into account the multiple benefits (or harmful effects) of certain energy production technologies [20]. Also, it is likely that Finnish energy discourses still carry the legacy of the highly centralised energy system prioritising the need to provide energy for large-scale industrial plants. Decentralised and currently minor energy sources, such as biogas, have not yet fully challenged the Finnish energy regime that is strongly based on centralised energy production. The adoption of small-scale biogas technologies is still in its elongated early phase, with clear potential for rapid expansion and forming part of a regime through a socio-technological transition.

\section{Conclusions}

The newspaper coverage of biogas in Finland showed an increasing and relatively high volume of specialised news coverage, presence of multiple actors voicing their views, and a dominant framing of biogas as a potential energy solution with multiple benefits and a strong temporal focus on future issues. The news coverage was strongly influenced by the activities of a few forerunners of biogas production and some prominent policymakers interested in promoting biogas. Media contents are one factor influencing the lock-ins and transformations of energy production and consumption, among many other contributing factors. As shown by the Finnish newspaper 
coverage, positive public framings are not able to spark a large-scale energy transition alone. Despite more than a decade of news coverage framing biogas as a highly promising energy source with several co-benefits, the volume of energy produced from biogas has remained negligible in Finland.

In particular, the potential of small-scale farm-based biogas production remains underutilised in Finland. News coverage highlighting not only the environmental benefits but also the poor economic profitability and the reliance on unpredictable public subsidies may discourage early adopters that are considering investments in the biogas technology. It should be emphasised that media representations deliver multiple messages that can be interpreted in different ways, depending on the context and the values, worldviews and interests of the receiver of the information. Therefore, future studies should include additional analyses of media contents and the contextsensitive interplay between media and other factors influencing energy transitions.

\section{Acknowledgements}

We warmly thank the anonymous referees, Marileena Mäkelä, Vilja Varho and Erika Winquist, for the constructive comments.

\section{Funding}

This research was funded by the Academy of Finland under the FutWend project (297742)

\section{Availability of data and materials}

Data will be available from the Finnish Social Science Data Archive after the finalisation of the FutWend project.

\section{Authors' contributions}

$J L$ planned the study design. $J$ and AP were responsible for the collection of the data and coding. All authors participated on the analysis and interpretation of data and drafting the article. All authors read and approved the final manuscript.

\section{Competing interests}

The authors declare that they have no competing interests

\section{Publisher's Note}

Springer Nature remains neutral with regard to jurisdictional claims in published maps and institutional affiliations.

\section{Author details}

${ }^{1}$ Finnish Environment Institute, Helsinki, Finland. ${ }^{2}$ Finland Futures Research Centre, University of Turku, Turku, Finland.

Received: 9 October 2017 Accepted: 5 April 2018

Published online: 04 June 2018

\section{References}

1. Lacy P, Rutqvist J (2016) Waste to wealth: the circular economy advantage Palgrave Macmillan, London

2. Arthurson V (2009) Closing the global energy and nutrient cycles through application of biogas residue to agricultural land-potential benefits and drawback. Energies 2(2):226-242. https://doi.org/10.3390/en20200226

3. Mol APJ (2014) Bounded biofuels? Sustainability of global biogas developments. Sociol Ruralis 54(1):1-20. https://doi.org/10.1111/soru.12026

4. Surendra KC, Takara D, Hashimoto AG, Khanal SK (2014) Biogas as a sustainable energy source for developing countries: opportunities and challenges. Renew Sust Energ Rev 31:846-859. https://doi.org/10.1016/j.rser.2013.12.015
5. Mao C, Feng Y, Wang X, Ren G (2015) Review on research achievements of biogas from anaerobic digestion. Renew Sust Energ Rev 45:540-555. https://doi.org/10.1016/j.rser.2015.02.032

6. Muvhiiwa R, Hildebrandt D, Chimwani N, Ngubevana L, Matambo T (2017) The impact and challenges of sustainable biogas implementation: moving towards a bio-based economy. Energy Sustain Soc 7(1):20. https://doi.org/10. 1186/s13705-017-0122-3

7. Winquist E, Luostarinen S, Kässi P, Pyykkönen V, Regina K (2015) Maatilojen biokaasulaitosten kannattavuus ja kasvihuonekaasujen päästövähennys. Helsinki, Luonnonvarakeskus

8. Kinsella WJ (2005) One hundred years of nuclear discourse: four master themes and their implications for environmental communication. Environ Commun Yearb 2:49-72

9. Peterson TR, Stephens JC, Wilson EJ (2015) Public perception of and engagement with emerging low-carbon energy technologies: a literature review. MRS Energ Sustain 2:E11. https://doi.org/10.1557/mre. 2015.12

10. Magnani N (2012) Exploring the local sustainability of a green economy in alpine communities. Mt Res Dev 32(2):109-116. https://doi.org/10.1659/MRDJOURNAL-D-11-00105.1

11. Markard J, Wirth S, Truffer B (2016) Institutional dynamics and technology legitimacy — a framework and a case study on biogas technology. Res Policy 45(1):330-344. https://doi.org/10.1016/j.respol.2015.10.009

12. EurObserv'ER (2014) Biogas barometer 2014. https://www.eurobserv-er.org/ biogas-barometer-2014/. [Accessed 27 Sept 2017]

13. Lambert M (2017) Biogas: a significant contribution to decarbonising gas markets? The Oxford Institute for Energy Studies. https://www.oxfordenergy. org/publications/biogas-significant-contribution-decarbonising-gas-markets/ [Accessed 27 Sept 2017]

14. Sovacool BK (2017) Contestation, contingency, and justice in the Nordic low-carbon energy transition. Energ Policy 102:569-582. https://doi.org/10. 1016/j.enpol.2016.12.045

15. Myllyntaus T (2010) Switching to a biofuel at the pinch: wood gas in Finnish motoring during World War II. Icon 16:101-122

16. Geels FW, Raven RPJM (2007) Socio-cognitive evolution and co-evolution in competing technical trajectories: biogas development in Denmark (1970-2002). Int J Sust Dev World Ecol 14(1):63-77. https://doi.org/10.1080/13504500709469708

17. Karlsson NPE, Halila F, Mattsson M, Hoveskog M (2017) Success factors for agricultural biogas production in Sweden: a case study of business model innovation. J Clean Prod 142:2925-2934. https://doi.org/10.1016/j.jclepro.2016.10.178

18. Olsson L, Fallde M (2015) Waste(d) potential: a socio-technical analysis of biogas production and use in Sweden. J Clean Prod 98:107-115. https://doi. org/10.1016/j.jclepro.2014.02.015

19. Fevolden AM, Klitkou A (2017) A fuel too far? Technology, innovation, and transition in failed biofuel development in Norway. Energy Res Soc Sci 23: 125-135. https://doi.org/10.1016/j.erss.2016.10.010

20. Huttunen S, Kivimaa P, Virkamäki V (2014) The need for policy coherence to trigger a transition to biogas production. Environ Innov Soc Transit 12:14-30. https://doi.org/10.1016/j.eist.2014.04.002

21. Nygrén NA, Kontio $P$, Lyytimäki J, Varho V, Tapio $P$ (2015) Early adopters boosting the diffusion of sustainable small-scale energy solutions. Renew Sust Energ Rev 46:79-87. https://doi.org/10.1016/j.rser.2015.02.031

22. Varho V, Rikkonen P, Rasi S (2016) Futures of distributed small-scale renewable energy in Finland - a Delphi study of the opportunities and obstacles up to 2025. Technol Forecast Soc Change 104:30-37. https://doi. org/10.1016/j.techfore.2015.12.001

23. Cox R (2012) Environmental communication and the public sphere, 3rd edn. Sage, Thousand Oaks, CA

24. Lyytimäki J, Tapio P, Varho V, Söderman T (2013) The use, non-use and misuse of indicators in sustainability assessment and communication. Int J Sust Dev World Ecol 20(5):385-393. https://doi.org/10.1080/13504509.2013.834524

25. Sengers F, Raven RPJM, Van Venrooij A (2010) From riches to rags: biofuels, media discourses, and resistance to sustainable energy technologies. Energ Policy 38(9):5013-5027. https://doi.org/10.1016/j.enpol.2010.04.030

26. Lyytimäki J, Assmuth T, Hildén M (2011) Unrecognized, concealed, or forgotten-the case of absent information in risk communication. J Risk Res 14(6):757-773. https://doi.org/10.1080/13669877.2011.571773

27. Mullally G, Byrne E (2016) A tale of three transitions: a year in the life of electricity system transformation narratives in the Irish media. Energy Sustain Soc 6(1):3. https://doi.org/10.1186/s13705-015-0068-2

28. Kern F, Markard J (2016) Analysing energy transitions: combining insights from transition studies and international political economy. In: Van de Graaf 
T, Sovacool BK, Ghosh A, Kern F, Klare MT (eds) The Palgrave handbook of the international political economy of energy. Palgrave Macmillan UK, London, pp 291-318. https://doi.org/10.1057/978-1-137-55631-8_12

29. Schot J, Kanger L, Verbong $G$ (2016) The roles of users in shaping transitions to new energy systems. Nat Energy 1:16054. https:/doi.org/10.1038/ nenergy. 2016.54

30. Geels FW, Sovacool BK, Schwanen T, Sorrell S (2017) The socio-technical dynamics of low-carbon transitions. Joule 1(3):463-479. https://doi.org/10. 1016/j.joule.2017.09.018

31. Geels FW (2002) Technological transitions as evolutionary reconfiguration processes: a multi-level perspective and a case-study. Res Policy 31(8):12571274. https://doi.org/10.1016/50048-7333(02)00062-8

32. Geels FW, Schot J (2007) Typology of sociotechnical transition pathways. Res Policy 36(3):399-417. https://doi.org/10.1016/j.respol.2007.01.003

33. Hermwille $L$ (2016) The role of narratives in socio-technical transitions-Fukushima and the energy regimes of Japan, Germany, and the United Kingdom. Energy Res Soc Sci 11:237-246. https://doi.org/10.1016/j. erss.2015.11.001

34. Geels F, Raven R (2006) Non-linearity and expectations in nichedevelopment trajectories: ups and downs in Dutch biogas development (1973-2003). Tehcnol Anal Strat Manage 18(3-4):375-392. https://doi.org/10. 1080/09537320600777143

35. Pidgeon N, Fischhoff B (2011) The role of social and decision sciences in communicating uncertain climate risks. Nat Clim Chang 1:35. https:/doi.org/ 10.1038/nclimate1080

36. Ashmoore O, Evensen D, Clarke C, Krakower J, Simon J (2016) Regional newspaper coverage of shale gas development across Ohio, New York, and Pennsylvania: similarities, differences, and lessons. Energy Res Soc Sci 11:119132. https://doi.org/10.1016/..erss.2015.09.005

37. Skjølsvold TM (2012) Curb your enthusiasm: on media communication of bioenergy and the role of the news media in technology diffusion. Environ Commun 6(4):512-531. https://doi.org/10.1080/17524032.2012.705309

38. Kunelius R, Eide E (2012) Moment of hope, mode of realism: on the dynamics of a transnational journalistic field during UN climate change summits. Int J Commun 6(1):266-286

39. Energiavirasto (2017) Uusiutuva energia tuotantoennätykseen. http///www energiavirasto.fi-/uusiutuva-energia-tuotantoennatykseen. [Accessed 6 Feb 2018]

40. Huttunen MJ, Kuittinen V (2016) Suomen biokaasulaitosrekisteri n:o 19. University of Eastern Finland, Joensuu

41. Adamiak C, Vepsäläinen M, Strandell A, Hiltunen M, Pitkänen K, Hall M, Rinne J, Hannonen O, Paloniemi R, Åkerlund U (2015) Second home tourism in Finland-perceptions of citizens and municipalities on the state and development of second home tourism. Helsinki, Finnish Environment Institute

42. Huttunen R (ed) (2017) Government report on the National Energy and Climate Strategy for 2030. Helsinki, Ministry of Economic Affairs and Employment

43. Heiskanen E, Lovio R, Louhija K (2014) Miten uusi teknologia tulee uskottavaksi: esimerkkinä maalämpö Suomessa. Liiketaloudellinen Aikakauskirja 63(4):227-298

44. MediaAuditFinland (2017) LT JA JT Tarkastustilasto 2016. http://mediaauditfinland. fi/wp-content/uploads/2017/06/Levikkitilasto-2016.pdf. Accessed 27 Sept 2017.

45. Lyytimäki J (2015) Prospects for environmental communication based on 25 years of newspaper coverage of climate change and eutrophication in Finland. Appl Environ Educ Commun 14(4):246-255. https://doi.org/10.1080/ 1533015X.2015.1109486

46. Huttunen S (2009) Ecological modernisation and discourses on rural nonwood bioenergy production in Finland from 1980 to 2005. J Rural Stud 25(2):239-247. https://doi.org/10.1016/j.jurstud.2008.10.001

47. Benford RD, Snow DA (2000) Framing processes and social movements: an overview and assessment. Annu Rev Socio/ 26(1):611-639. https://doi.org/10. 1146/annurev.soc.26.1.611

48. Lombard M, Snyder-Duch J, Bracken CC (2002) Content analysis in mass communication: assessment and reporting of intercoder reliability. Hum Commun Res 28(4):587-604. https://doi.org/10.1111/j.1468-2958.2002.tb00826.x

49. Kaparaju P (2003) Enhancing methane production in a farm-scale biogas production system. University of Jyväskylä, Jyväskylä

50. Litmanen T, Kojo M (2011) Not excluding nuclear power: the dynamics and stability of nuclear power policy arrangements in Finland. J Integr Environ Sci 8(3):171-194. https://doi.org/10.1080/1943815X.2011.585652
51. Lyytimäki J (2011) Mainstreaming climate policy: the role of media coverage in Finland. Mitig Adapt Strat Global Change 16(6):649-661. https://doi.org/10. 1007/s11027-011-9286-X

52. Lyytimäki J, Assmuth T (2017) Absent information in integrative environmental and health risk communication. In: Parrott R (ed) Encyclopedia of health and risk message design and processing. Oxford University Press, New York. https://doi.org/10.1093/acrefore/9780190228613.013.534

53. Kivimaa P, Mickwitz P (2011) Public policy as a part of transforming energy systems: framing bioenergy in Finnish energy policy. J Clean Prod 19(16): 1812-1821. https://doi.org/10.1016/j.jclepro.2011.02.004

54. Ruostetsaari I (2010) Changing regulation and governance of Finnish energy policy making: new rules but old elites? Rev Policy Res 27(3):273-297. https://doi.org/10.1111/j.1541-1338.2010.00442.x

55. Haukkala T (2017) A struggle for change-the formation of a greentransition advocacy coalition in Finland. Environ Innov Soc Transit. https://doi.org/10.1016/j.eist.2017.12.001

56. Teräväinen T (2011) Representations of energy policy and technology in British and Finnish newspaper media: a comparative perspective. Public Underst Sci 23(3):299-315. https://doi.org/10.1177/0963662511409122

57. Pfau SF, Hagens JE, Dankbaar B (2017) Biogas between renewable energy and bio-economy policies_opportunities and constraints resulting from a dual role. Energy Sustain Soc 7(1):17. https://doi.org/10.1186/s13705-017-0120-5

58. Helenius J, Koppelmäki K, Virkkunen E (eds) (2017) Agroekologinen symbioosi ravinne- ja energiaomavaraisessa ruoantuotannossa. Helsinki, Ympäristöministeriö

59. Lybæk R, Christensen TB, Kiær T (2013) Governing innovation for sustainable development in the Danish biogas sector-a historical overview and analysis of innovation. Sustain Dev 21(3):171-182. https://doi.org/10.1002/sd.1548

60. Negro SO, Hekkert MP, Smits RE (2007) Explaining the failure of the Dutch innovation system for biomass digestion - a functional analysis. Energ Policy 35(2):925-938. https://doi.org/10.1016/j.enpol.2006.01.027

61. Bruns E, Ohlhorst D, Wenzel B, Köppel J (2010) Renewable energies in Germany's electricity market: a biography of the innovation process. Springer, Heidelberg

62. Herbes C, Jirka E, Braun JP, Pukall K (2014) The social discourse on the "maize cap" before and after the 2012 amendment of the German Renewable Energies Act (EEG). GAIA 23(2): 100-108. doi:10.14512/gaia.23.2.7

63. Demirbas A (2017) Future hydrogen economy and policy. Energ Source Part B 12(2):172-181. https://doi.org/10.1080/15567249.2014.950394

\section{Submit your manuscript to a SpringerOpen ${ }^{\circ}$ journal and benefit from:}

- Convenient online submission

- Rigorous peer review

- Open access: articles freely available online

- High visibility within the field

- Retaining the copyright to your article

Submit your next manuscript at $\boldsymbol{\nabla}$ springeropen.com 